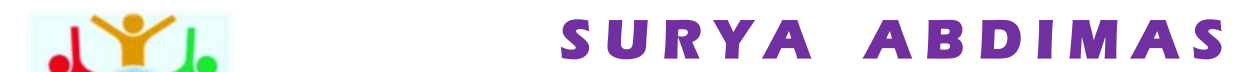

Vol. 5 No. 3 (2021) pp. 185 - 192

Available online at: http://jurnal.umpwr.ac.id/index.php/abdimas/index

p-ISSN: 2580-3492 e-ISSN: $\underline{2581-0162}$

\title{
Pelatihan Pembelajaran Daring Menggunakan Google Classroom di SMP Muhammadiyah se-Kecamatan Pleret
}

\section{Dian Ariesta Yuwaningsih $\bowtie$, Rusmining}

\section{Universitas Ahmad Dahlan}

Jl. Ringroad Selatan, Kragilan, Kec. Banguntapan, Bantul, Yogyakarta 55191, Indonesia

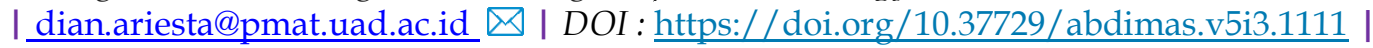

\begin{abstract}
Abstrak
Pada era pandemi saat ini, pembelajaran di Indonesia dilakukan secara daring. Salah satu aplikasi pembelajaran daring yang mudah dan praktis diakses oleh berbagai kalangan adalah Google Classroom. Berdasarkan hasil wawancara terhadap beberapa pendidik matematika di SMP Muhammadiyah Pleret dan MBS Pleret diketahui bahwa para pendidik matematika di sana belum ada yang memanfaatkan pembelajaran daring seperti Google Classroom. Pendidik masih belum mengenal Google Classroom. Saat ini, para pendidik melakukan pembelajaran daring dengan menggunakan Google Form. Kegiatan Program Kemitraan Masyarajat (PKM) ini memiliki tujuan memberikan pelatihan dan pendampingan pembelajaran daring menggunakan Google Classroom bagi pendidik matematika di SMP Muhammadiyah se-kecamatan Pleret. Kegiatan PKM ini dilaksanakan secara daring melalui aplikasi Google Meet pada tanggal 14-16 Oktober 2020. Peserta kegiatan PKM ini terdiri atas semua pendidik matematika sebanyak 10 orang yang meliputi pendidik di SMP Muhammadiyah Pleret dan pendidik di MBS Pleret. Kegiatan ini menggunakan metode penyuluhan, pelatihan, dan pendampingan. Hasil dari kegiatan ini adalah sebanyak 93\% pendidik matematika sangat setuju serta $7 \%$ pendidik matematika setuju dengan diadakannya kegiatan pelatihan pembelajaran daring menggunakan Google Classroom. Dengan demikian, kegiatan ini memberikan manfaat bagi para pendidik matematika di SMP Muhammadiyah sekecamatan Pleret.

Kata Kunci: Google Classroom, Pelatihan, Daring
\end{abstract}

(c) (i) (8) This work is licensed under a Creative Commons Attribution-NonCommercial 4.0
International License

\section{Pendahuluan}

Seiring semakin pesatnya perkembangan teknologi informasi dan komunikasi saat ini, salah satunya dalam bidang media pembelajaran, terdapat banyak sekali peneliti yang menciptakan software media pembelajaran agar dapat mempermudah dalam proses belajar mengajar (Mayasari et al., 2019). Salah satu contoh software media pembelajaran yang dimaksud adalah Google Classroom.

Salah satu kewajiban seorang pendidik adalah mempelajari serta memahami perkembangan teknologi. Penggunaan pembelajaran yang masih tradisional dimana pendidik memberi materi di depan kelas kemudian menerangkan mata pelajaran dirasakan masih memiliki kekurangan. Bagi peserta didik yang dapat hadir di kelas mungkin tidak masalah, tetapi bila salah satu peserta didik, karena suatu hal, tidak dapat menghadiri pembelajaran tersebut di kelas maka akan tertinggal dalam mendapatkan pengetahuan yang seharusnya diperoleh. Apabila pendidik tidak bisa 
memberikan materi di depan kelas tetapi harus menyampaikan materi tersebut saat itu juga, maka hal ini juga dirasa sulit dalam kondisi saat itu.

Pembelajaran daring menggunakan Google Classroom sangat relevan digunakan untuk model pembelajaran secara daring (Fauziah et al., 2019). Misalnya seperti kondisi saat ini, semua penjuru dunia sedang dilanda wabah pandemi Covid-19. Covid-19 merupakan suatu penyakit baru yang belum pernah teridentifikasi sebelumnya pada manusia. Adapun gejala umum infeksi Covid-19 adalah terjadinya gangguan pernafasan akut seperti batuk, demam, serta sesak napas. Masa inkubasi virus ini ratarata selama lima hingga enam hari dengan masa inkubasi terpanjang selama 14 hari. Berbagai negara telah menerapkan isolasi, yaitu proses pemisahan orang sakit dengan penyakit menular dari orang yang tidak terinfeksi dengan tujuan melindungi orang yang tidak terinfeksi (Smith \& Freedman, 2020). Virus ini telah menyebar dengan sangat cepat hampir ke berbagai penjuru dunia. Munculnya virus berbahaya ini berdampak pada berbagai sektor, salah satunya termasuk sektor Pendidikan (Rihani, 2020).

Dalam aktifitas bermasyarakat, pandemi Covid-19 ini menyebabkan berbagai perubahan. Indonesia merupakan salah satu negara yang terkena dampak dari pandemi Covid-19. Pemerintah secara resmi meminta pihak-pihak terkait untuk mengurangi pembelajaran tatap muka langsung atau meminimalisir kontak langsung antar manusia. Pembelajaran daring dinilai efektif untuk menghindari penyebaran wabah virus ini (Rihani, 2020). Menurut (Agung \& Rohman, 2020) pembelajaran daring sendiri ialah suatu proses pembelajaran dengan menggunakan jaringan internet dengan aksesbilitas, konektivitas, fleksibelitas dan kemampuan menampilkan berbagai jenis interaksi pembelajaran. Namun, menurut (Attin et al., 2020) dengan adanya perubahan dalam proses pembelajaran yang dilakukan secara tiba-tiba membuat para pendidik, peserta didik, maupun orang tua kurang persiapan yang matang dalam menerima proses pembelajaran secara daring.

Pembelajaran daring menuntut pendidik untuk menggunakan media pembelajaran berbasis teknologi informasi sehingga dapat membantu pendidik dalam mengelola aktivitas pembelajaran secara efektif dan efisien meskipun tidak ada interaksi secara langsung antara pendidik dan peserta didik (Sumarno, 2020). Pemanfaatan teknologi telah menjadi salah satu cara yang efektif dalam melaksanakan pembelajaran daring di tengah situasi pandemi sekarang ini (Pujiasih, 2020). Namun, penggunaan teknologi dalam pembelajaran seringkali terkendala oleh keterbatasan penguasaan teknologi oleh pendidik dan peserta didik, sarana dan prasarana yang kurang memadai, serta keterbatasan akses intenet (Syah, 2020). Para pendidik dituntut agar mampu beradaptasi ke pembelajaran daring, hal ini menmpulkan masalah karena para pendidik mayoritas belum pernah mendapatkan pengetahuan dan ketrampilan mengenai jenisjenis platform pembelajaran daring, khususnya Google Classroom.

Google Classroom sendiri merupakan software pembelajaran daring yang dapat diakses secara gratis. Menurut (Sudarsana et al., 2019),Google Classroom merupakan salah satu produk Google untuk pendidikan. Google Classroom mudah digunakan oleh pendidik dan peserta didik serta telah terintegrasi dengan sosial media dan produk Google lainnya seperti Google Drive, Google Form, Google Doc, dan Google Slide(Ramadhani et al., 2019). Selain itu, Google Classroom menyediakan berbagai fitur yang memudahkan dalam mengelola aktivitas kelas secara efektif dalam memfasilitasi pembelajaran daring (Arizona et al., 2020). Pendidik dapat membuat kelas sendiri dan membagikan kode kelas tersebut kepada para peserta didiknya agar mereka dapat bergabung di kelas tersebut. Google Classroom ini dapat diakses oleh semua ruang lingkup pendidikan dan dapat meringankan peserta didik dalam menemukan serta mengatasi kesulitan 
pembelajaran, membagikan pelajaran, serta membuat tugas tanpa harus hadir di kelas. Oleh karena itu, berbagai bentuk pelatihan Google Classroom mulai dilaksanakan guna membekali para peserta didik di beberapa sekolah (Sujana et al., 2019); (Ahmad et al., 2020); (Arizona et al., 2020). Meskipun beberapa pelatihan terkait Google Classroom telah dilaksanakan sebelumnya di beberapa sekolah, namun belum menjangkau semua wilayah di Indonesia. Beberapa sekolah masih meminta peserta didik secara bertahap dan terjadwal untuk datang ke sekolah untuk mengambil tugas atau mengumpulkan tugas dengan tetap mematuhi protokol kesehatan. Tentu saja hal ini dapat dihindari jika para pendidik di sekolah telah mampu memenfaatkan teknologi untuk pembelajaran daring.

Berdasarkan hasil wawancara dengan para pendidik matematika di SMP Muhammadiyah Pleret dan MBS Pleret, diperoleh bahwa pembelajaran matematika di SMP Muhammadiyah se-Kecamatan Pleret masih belum memanfaatkan pembelajaran daring dengan menggunakan software Google Classroom. Pendidik masih belum mengenal Google Classroom, sehingga pembelajaran masih terbatas pada tatap muka langsung di kelas. Saat pandemi ini, para pendidik melakukan pembelajaran lewat Google Form. Oleh karena itu, mereka tertarik dengan adanya pelatihan pembelajaran daring menggunakan Google Classroom. Adapun tujuan dari kegiatan Program Kemitraan Masyarakat ini adalah memberikan pelatihan dan pendampingan pembelajaran daring menggunakan Google Classroom bagi para pendidik matematika di SMP Muhammadiyah se-Kecamatan Pleret, Bantul. Pentingnya kegiatan pelatihan Google Classroom ini dilaksanakan agar dapat membantu para pendidik untuk memahami tentang Google Classroom sehingga dapat menerapkannya dalam proses pembelajaran daring di SMP Muhammadiyah se-kecamatan Pleret. Dengan adanya kegiatan PKM ini diharapkan pendidik mampu membuat akun dan grup kelas Google Classroom, serta mengoperasikannya.

\section{Metode}

Kegiatan Program Kemitraan Masyarakat (PKM) ini diselengarakan pada bulan Oktober 2020 tepatnya pada tanggak 14-16 Oktober 2020. Kegiatan PKM ini dilaksanakan secara daring melalui Google Meet. Metode pelaksanaan kegiatan pelatihan pembelajaran daring menggunakan Google Classroom dilakukan dengan tiga cara, yaitu kegiatan penyuluhan; kegiatan pelatihan; serta kegiatan pendampingan. Kegiatan diawali dengan penyuluhan materi tentang Google Classroom dan penggunaanya. Kemudian dilanjutkan dengan pelatihan pembelajaran daring menggunakan Google Classroom. Terakhir diselenggarakan kegiatan pendampingan berupa praktik pembelajaran daring menggunakan Google Classroom.

Kegiatan pelatihan ini diikuti sebanyak sepuluh pendidik matematika dari SMP Muhammadiyah Se-Kecamatan Pleret, Bantul. Selain itu, kegiatan ini juga dibantu oleh dua orang mahasiswa sebagai Tim Pengabdi. Adapun peran Tim Pengabdi yaitu sebagai narasumber pada kegiatan penyuluhan, pelatihan, hingga kegiatan pendampingan. Tim pengabdi memberikan penyuluhan tentang pembelajaran daring menggunakan Google Classroom, kemudian dilanjutkan dengan pelatihan pemanfaatan Google Classroom dalam proses pembelajaran yang dibantu oleh seorang mahasiswa. Selanjutnya, kegiatan pendampingan dilakukan oleh Tim Pengabdi dibantu dua orang mahasiswa. Di sisi lain, peran Mitra sendiri adalah sebagai peserta kegiatan penyuluhan, pelatihan, dan pendampingan. 


\section{Hasil dan Pembahasan}

Kegiatan Program Kemitraan Masyarakat (PKM) ini dilaksanakan selama tiga hari, yaitu pada tanggal 14 Oktober 2020 hingga tanggal 16 Oktober 2020. Seluruh kegiatan ini sepenuhnya dilaksanakan secara daring melalui aplikasi Google Meet. Hari pertama kegiatan pelatihan diisi dengan penyuluhan tentang Google Classroom dan penggunaanya. Kemudian hari kedua diisi dengan pelatihan tentang tata cara mengelola pembelajaran daring menggunakan Google Classroom. Pada hari ketiga, dilakukan kegiatan pendampingan berupa praktik pembelajaran daring menggunakan Google Classroom. Kegiatan penyuluhan dan pelatihan ini diikuti oleh pendidik matematika SMP Muhammadiyah Pleret dan pendidik matematika MBS Pleret dengan total sebanyak sepuluh orang pendidik. Sedangkan saat kegiatan pendampingan, dipilih seorang pendidik matematika dari SMP Muhammadiyah Pleret untuk praktik pembelajaran daring dengan menggunakan Google Classroom. Adapun beberapa dokumentasi dari kegiatan ini disajikan pada Gambar 1.

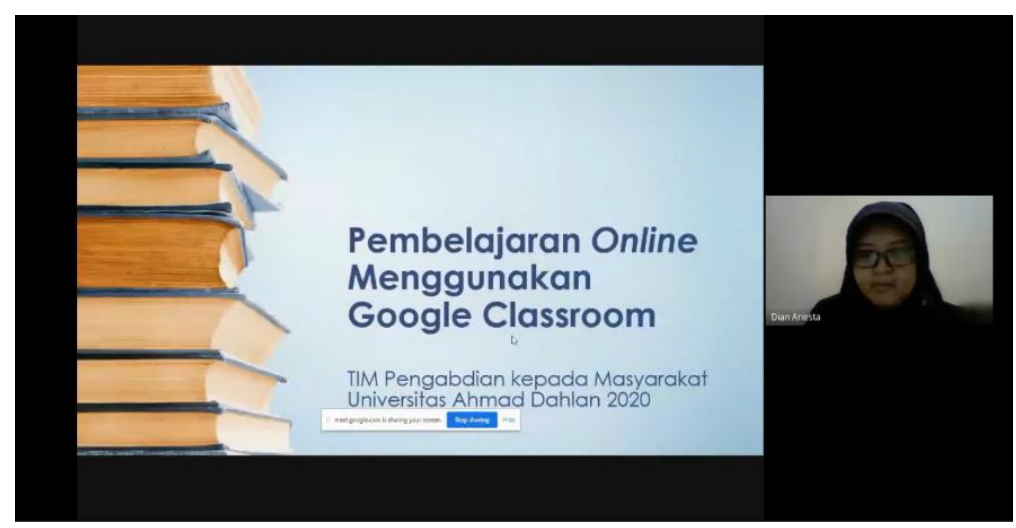

Gambar 1a. Pemaparan Materi tentang Google Classroom

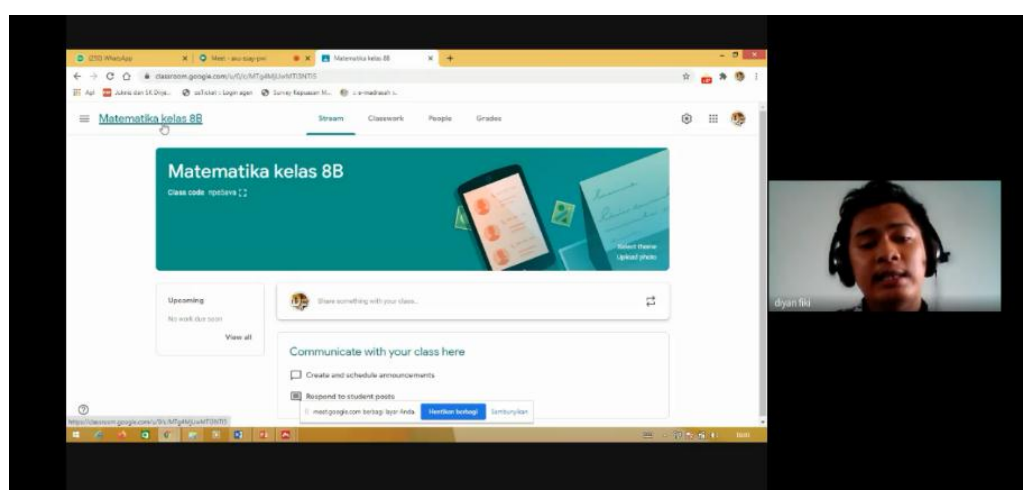

Gambar 1b. Pelatihan Pembelajaran Daring Menggunakan Google Classroom

Pada akhir kegiatan pelatihan, setiap pendidik diminta untuk mengisi kuisioner secara daring melalui Google Form. Kuisioner ini digunakan untuk mengukur tingkat keberdayaan mitra. Berdasarkan hasil kuisioner yang dibagikan kepada sepuluh orang pendidik matematika, diperoleh hasil seperti disajikan pada Tabel 1. 
Tabel 1. Hasil Kuisioner Pembelajaran Daring Menggunakan Google Classroom

\begin{tabular}{|c|c|c|c|c|}
\hline \multirow{2}{*}{ No } & \multirow{2}{*}{ Pernyataan } & \multicolumn{3}{|c|}{ Penilaian (\%) } \\
\hline & & SS & S $\quad$ KS $\quad$ TS & STS \\
\hline $\mathbf{1}$ & $\begin{array}{l}\text { Kegiatan pelatihan dan pendampingan ini } \\
\text { memberikan wawasan kepada pendidik tentang } \\
\text { pembelajaran daring }\end{array}$ & 92 & 8 & \\
\hline 2 & $\begin{array}{l}\text { Kegiatan pelatihan dan pendampingan ini } \\
\text { memberikan wawasan kepada pendidik tentang } \\
\text { pembelajaran daring menggunakan Google } \\
\text { Classroom }\end{array}$ & 94 & 6 & \\
\hline 3 & $\begin{array}{l}\text { Kegiatan pelatihan ini membantu pendidik dalam } \\
\text { merancang pembelajaran daring menggunakan } \\
\text { Google Classroom }\end{array}$ & 90 & 10 & \\
\hline 4 & $\begin{array}{l}\text { Kegiatan pelatihan ini memotivasi pendidik } \\
\text { untuk praktik pembelajaran daring menggunakan } \\
\text { Google Classroom }\end{array}$ & 92 & 8 & \\
\hline 5 & $\begin{array}{l}\text { Sekolah sangat terbantu dengan adanya kegiatan } \\
\text { pelatihan dan pendampingan pembelajaran } \\
\text { daring menggunakan Google Classroom }\end{array}$ & 92 & 8 & \\
\hline 6 & $\begin{array}{l}\text { Perlu ada kegiatan pelatihan dan pendampingan } \\
\text { lanjutan terkait pembelajaran daring } \\
\text { menggunakan Google Classroom atau sejenisnya } \\
\text { untuk waktu yang akan datang }\end{array}$ & 94 & 6 & \\
\hline & Rata-rata & 93 & 7 & \\
\hline
\end{tabular}

Berdasarkan hasil kuisioner tersebut diperoleh bahwa sebanyak 92\% pendidik sangat setuju bahwa kegiatan pelatihan dan pendampingan ini dapat menambah wawasan pendidik terkait pembelajaran daring. Selain itu, diperoleh hasil bahwa sebanyak $94 \%$ pendidik sangat setuju bahwa kegiatan pelatihan dan pendampingan ini memberikan wawasan kepada pendidik tentang pembelajaran daring menggunakan Google Classroom. Sebanyak $90 \%$ pendidik juga sangat setuju jika kegiatan pelatihan ini membantu pendidik dalam merancang pembelajaran daring menggunakan Google Classroom. Selain itu, sebanyak $92 \%$ pendidik juga sangat setuju bahwa kegiatan pelatihan ini memotivasi pendidik untuk praktek pembelajaran daring menggunakan Google Classroom. Disamping itu, sebanyak 92\% pendidik sangat setuju bahwa sekolah merasa sangat terbantu dengan adanya kegiatan pelatihan dan pendampingan pembelajaran daring menggunakan Google Classroom ini. Persentase sebesar 94\% pendidik sangat setuju jika perlu ada kegiatan pelatihan dan pendampingan lanjutan terkait pembelajaran daring menggunakan Google Classroom atau sejenisnya untuk waktu yang akan datang. Pelaksanaan pelatihan secara daring ini dapat ditunjukkan pada Gambar 2. 


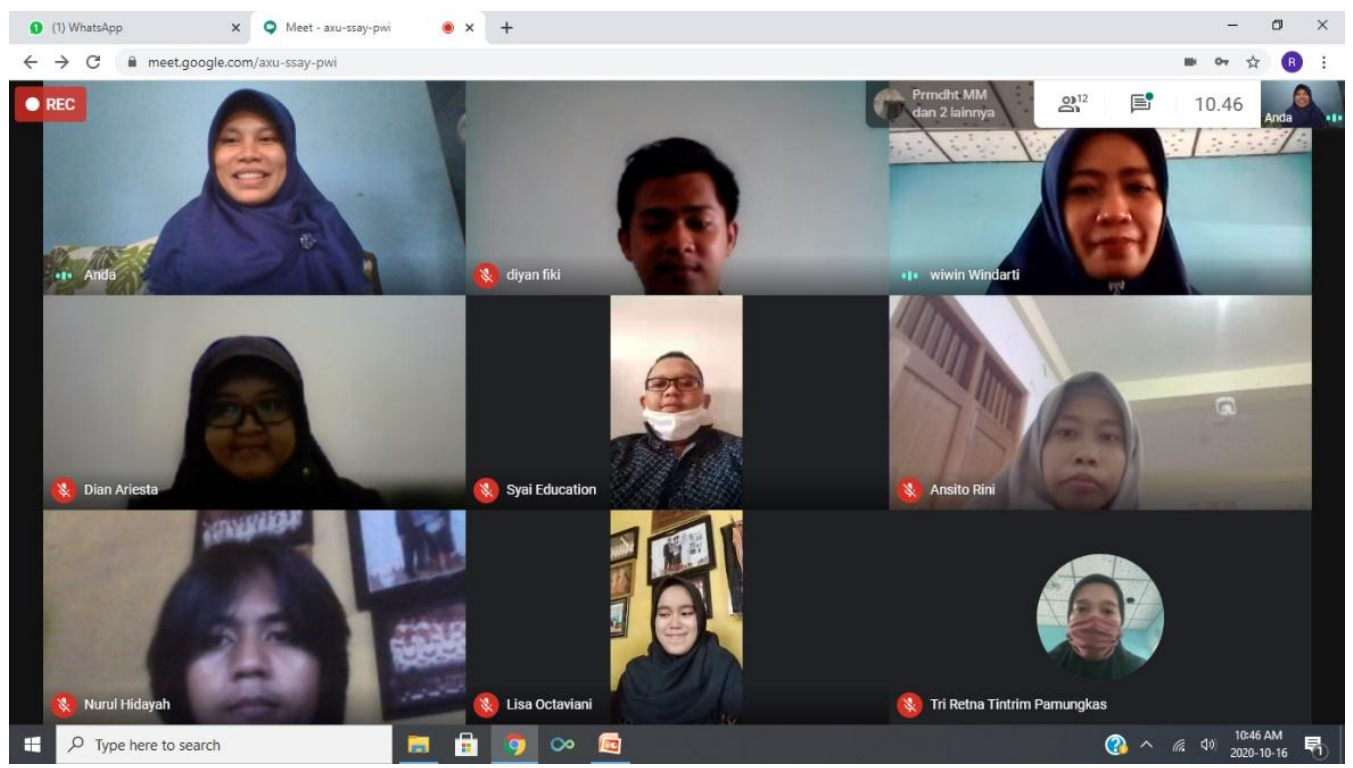

Gambar 2. Kegiatan Pelatihan Secara Daring

Secara umum, berdasarkan kuisioner tersebut diperoleh bahwa rata-rata sebanyak $93 \%$ pendidik sangat setuju dan sebanyak $7 \%$ pendidik setuju dengan kegiatan pelatihan pembelajaran daring menggunakan Google Classroom. Beberapa kritik dan komentar yang diberikan pendidik terkait kegiatan pelatihan dan pendampingan ini diantaranya adalah: (1) kegiatan pelatihan sangat bagus dan menarik; (2) penyampaian materi terlalu cepat; (3) pelatihan ini dapat mempermudah dalam pembelajaran matematika secara daring. Sedangkan saran yang diberikan diantaranya adalah: (1) perlu ditambahkan waktu pelatihannya, sehingga kegiatan praktiknya lebih panjang; (2) perlu diberi pelatihan tentang media pembelajaran yang lain; (3) pelatihan ini dirasa lebih efektif apabila dilakukan di awal semester.

Kegiatan ini dilaksanakan di pertengahan semester karena menyesuaikan jadwal kegiatan pengabdian universitas, sehingga beberapa peserta merasakan kurang efektifnya kegiatan ini. Lebih lanjut, secara keseluruhan adapaun komentar dan saran dari pihak mitra ini nanti akan digunakan sebagai bahan evaluasi dalam menentukan tema dan pelaksanaan kegiatan pengabdian pada tahun berikutnya.

Berdasarkan komentar dan saran dari pihak mitra dapat dikatakan bahwa kegiatan pelatihan terhadap para pendidik matematika di SMP Muhammadiyah sekecamatan Pleret berjalan baik dan lancar. Hal ini dapat membuktikan bahwa kegiatan pelatihan ini dapat memberikan manfaat kepada para pendidik. Selain itu, kegiatan ini dapat membantu para pendidik untuk mengimplementasikannya di kelas. Hal ini bertujuan untuk meningkatkan kualitas pembelajaran guna terwujudnya tujuan pembelajaran yang telah ditentuukan, sehingga hasil capaian ini sesuai dengan (Megahantara, 2017) teorinya bahwa penggunaan teknologi dapat memberikan dampak positif dalam kegiatan pembelajaran. 


\section{Kesimpulan}

Program Kemitraan Masyarakat (PKM) berupa pelatihan pembelajaran daring menggunakan Google Classroom bagi para pendidik matematika di SMP Muhammadiyah se-kecamatan Pleret berjalan dengan baik dan lancar. Selai itu, kegiatan PKM ini dapat memberikan manfaat bagi para pendidik. Hal ini terlihat dari hasil kuisioner yang dibagikan kepada para pendidik setelah kegiatan pengabdian ini berakhir. Berdasarkan hasil kuisioner diperoleh bahwa sebanyak $93 \%$ pendidik sangat setuju dan sebanyak $7 \%$ pendidik setuju dengan kegiatan pelatihan pembelajaran daring menggunakan Google Classroom.

\section{Acknowledgement}

Penulis mengucapkan terima kasih kepada mitra kegiatan PKM ini yaitu pendidik matematika di SMP Muhammadiyah se-Kecamatan Pleret atas kerjasamanya sehingga kegiatan ini dapat berangsung dengan lancar. Selain itu, penulis juga mengucapkan terima kasih kepada LPPM Universitas Ahmad Dahlan atas pemberian dana Hibah Pengabdian Regular Tahun 2020 Nomor L1/SPK-PPM-76/LPPM$\mathrm{UAD} / \mathrm{VI} / 2020$.

\section{Daftar Pustaka}

Agung, N. F., \& Rohman, T. (2020). Pelatihan Pembelajaran Daring Menggunakan WhatsApp. Jurnal Pengabdian Kepada Masyarakat AL-ABHATS, 1(1), Agung, N. F., Rohman, T. (2020). Pelatihan Pembe.

Ahmad, Negara, H. R. P., Ibrahim, M., \& Etmy, D. (2020). Pelatihan Pembelajaran Daring (Google Classroom) bagi Guru MTs dan MI Nurul Yaqin Kelanjur. JPMB : Jurnal Pemberdayaan Masyarakat Berkarakter, 3(1), 66-79.

Arizona, K., Abidin, Z., \& Rumansyah, R. (2020). Pembelajaran Online Berbasis Proyek Salah Satu Solusi Kegiatan Belajar Mengajar Di Tengah Pandemi Covid-19. Jurnal Ilmiah Profesi Pendidikan, 5(1), 64-70.

Attin, W., Adirakasiwi, A. G., \& Santoso, E. (2020). Motivasi Dan Kemandirian Belajar Siswa Pada Masa Pandemi COVID-19 (Studi Pada Siswa Kelas VII SMP N 3 Karawang Tahun Pelajaran 2019/2020). Jurnal Education and Development, 8(3).

Fauziah, U. N. El, Suryani, L., \& Syahrizal, T. (2019). Penerapan Google Classroom dalam Pembelajaran Bahasa Inggris Kepada Guru-Guru Bahasa Inggris SMP di Subang. Jurnal Abdimas Siliwangi, 2(2), 183-191.

Mayasari, F., Dwita, D., Jupendri, Jayus, Nazhifah, Hanafi, K., \& Putra, N. M. (2019).

Pelatihan Komunikasi Efektif Media Pembelajaran Google Classroom Bagi Guru

MAN 2 Model Pekanbaru. Jurnal Pengabdian Untuk Mu NegeRI, 3(1), 1k8-23.

Megahantara, G. S. (2017). Pengaruh Teknologi Terhadap Pendidikan di Abad 21. Universitas Negeri Yogyakarta.

Pujiasih, E. (2020). Membangun Generasi emas dengan Variasi Pembelajaran Online di Masa Pandemi Covid-19. Ideguru: Jurnal Karya Ilmiah Guru, 5(1). 
Ramadhani, R., Umam, R., Abdurrahman, A., \& Syazali, M. (2019). The effect of flippedproblem based learning model integrated with LMS-google classroom for senior high school students. Journal for the Education of Gifted Young Scientists, 7(2).

Rihani, N. N. (2020). Pembelajaran Jarak Jauh Dalam Masa Pandemi Covid-19. Jurnal LIS Scholarship, 6(1), 1-6.

Smith, W., \& Freedman, D. O. (2020). Isolation, quarantine, social distancing and community containment: pivotal role for old-style public health measures in the novel coronavirus (2019-nCoV) outbreak. Journal of Travel Medicine, 27(2), 1-4.

Sudarsana, I. K., Putra, I. B. M. A., Astawa, I. N. T., \& Yogantara, I. W. L. (2019). The use of Google classroom in the learning process. Journal of Physics: Conference Series, 1175(1).

Sujana, I. M., Waluyo, U., Soepriyanti, H., \& Arifuddin. (2019). Workshop pengembangan blended learning berbasis google classroom sebagai solusi pembelajaran dan penelitian tindakan kelas. Jurnal Pendidikan Dan Pengabdian Masyarakat, 2(1).

Sumarno. (2020). Adaptasi Sekolah Dalam Mengimplementasikan Pembelajaran Jarak Jauh Pada Masa Pandemi Covid-19 (Studi Kasus Smp Muhammadiyah Karanggeneng Kabupaten Lamongan). Jurnal Tarbiyah \& Ilmu Keguruan (JTIK) Borneo, 1(2).

Syah, R. H. (2020). Dampak Covid-19 pada Pendidikan di Indonesia: Sekolah, Keterampilan, dan Proses Pembelajaran. SALAM: Jurnal Sosial Dan Budaya Syar-I, $7(5)$. 